\title{
IDENTITY STRUGGLES OF ADULT RETURNERS
}

\author{
KATARÍNA ROZVADSKÁ
}

\begin{abstract}
This article addresses a perceived gap in higher education literature: there is very little writing that successfully combines the issues of individual learners who dropped out and then returned to higher education - the adult returners. To address this problem, the article draws upon data from the qualitative part of a larger research project that deals with non-traditional students in the Czech Republic. This article analyzes data from eight subjects with drop-out experience chosen from the initial corpus of thirty non-traditional students. The results indicate that adult learners have to deal with three central identities and with potential identity struggles as they interact: student identity, work identity, and familial identity. The final result of the interaction between these identities can be either the integration or the disintegration of identities, whereby one of the possible consequences of identity disintegration is to drop out from higher education.
\end{abstract}

\section{Keywords}

adult returners, drop-out, bigher education, narratives, identity struggles, adult learner identities 


\section{Introduction}

This article explores widening access and participation in higher education (HE) through the narratives of a specific section (adult students who leave but return to study) of the target group (adult students in HE). In the literature, this group of students is operationalized as adult returners (Slowey \& Schuetze, 2012); however, this name is also used to designate adult learners in general $^{1}$ (e.g. Mercer, 2010). Students who return after dropping out are also referred to as stop-outs (Woosley, 2003) or re-enrollments (Grau-Valldosera et al., 2019); some studies emphasize the break in schooling of these students (Bonham \& Luckie, 1993). The present article chooses the typology of Slowey and Schuetze (2012), in which adult returners are characterized as those who take advantage of flexibility in the higher education structures to drop in to higher education, having dropped out or deferred at an earlier stage for a variety of reasons. As $\mathrm{HE}$ has been expanding considerably in recent decades $^{2}$ and many university students do not graduate, university drop-outs constitute a growing group in the labor market (Schnepf, 2015). Moreover, research suggests that almost a quarter $(24.8 \%)$ of all enrolled university students in the Czech Republic (where this research take place) have already studied without attaining a degree in the past (Mazouch et al., 2018).

\section{Narrative identities and identity struggles}

The research shows that "student success in HE is dependent on the possession of a positive learner identity" (MacFarlane, 2018, p. 1201). Sfard and Prusak (2005) also confirm the importance of the role of identity for successful HE studies, as for these authors identity plays a critical role in determining whether the process of learning will end with what counts as success or with what is regarded as failure. As regards adult students, Brunton and Buckley (2020) explored successful adult learner identity formation in $\mathrm{HE}$, particularly the experience of overcoming struggles at the start of the first year of university studies, and they talk about the necessity of managing identities in the portfolio for successful studies. If students want to be successful in their studies, meaning to finish their studies, they have to balance all the pressures of other identities in their identity portfolio. But what exactly is meant by "identity"?

\footnotetext{
1 For the whole group of adult students in higher education, we use the term "non-traditional students" (Novotný et al., 2019; Rozvadská \& Novotný, 2019).

2 Between 1995 and 2009, enrollment in OECD countries rose by 25\% (Schnepf, 2015).
} 
Identity as a concept is the subject of continuing social and historical transformation (Chappell et al., 2003). Ecclestone (2007, p. 122) states that "interest in identity is a prominent feature of contemporary social science research." In the modern understanding of identity, Giddens (1984, 1991) and Beck (1992; Beck et al., 1994) both see this concept as a reflexive rewriting of the Self, "made possible by the continuous self-monitoring processes that characterise late modernity" (Chappell et al., 2003, p. 29). People also construct this reflexive self - the stories they produce about themselves upon reflection - in the context of the research interview (Bruner, 1996; Gee, 1999; Roth et al., 2005).

To this reflexive nature of identity, Ricoeur (1992) adds a narrative dimension by stating that when people create a narrative of events in their life, they are also explaining who they are and thus are constructing narrative identities. Furthermore, coming from the communities-of-practice framework (Lave \& Wenger, 1991), Brickhouse and Potter (2001) argue for considering identity not only as who one is but also as who one wants to become:

We understand identity to refer to one's understanding of herself in relation to both her past and potential future. Identity refers to ways in which one participates in the world and the ways in which others interpret that participation (p. 966).

McAdams' life story model of identity $(1985,1993,1996)$ agrees with this, seeing narrative identity as a "person's internalized and evolving life story, integrating the reconstructed past and imagined future" (McAdams \& McLean, 2013, p. 233); this definition will be used in this article. The idea that identity is a life story resonates with a number of important themes in developmental, cognitive, personality, and cultural psychology (McAdams, 2001). However, for a conceptual framework, this study selects the theory of biographical work (Bron \& Thunborg, 2017; Thunborg \& Bron, 2019), which explores the narrative identity from a biographical learning perspective. Within this theoretical perception, the narratives of adult students are seen as stories of identity formation and transformation through various phases of life. In the biographical work framework, the process of identity transformation always starts with identity struggles, defined as "struggles that people experience in different periods of life in relation to different social situations that are narrated retrospectively in their biographical story" (Thunborg \& Bron, 2019, p. 40). A drop-out experience can be viewed as a potential identity struggle, especially when the adults overcome it and return to HE. 


\section{Return of adult students to $\mathrm{HE}$ after dropping out}

In the European HE system, dropping out is often perceived negatively by institutions and governments, as it has an economic cost for them (Merrill, 2015). Within this context, leaving university without attaining a degree is viewed as an individual failure (Quinn et al., 2005). However, research suggests that for individuals, dropping out from university may not always be negative, as "benefits may be gained in terms of learning, identity, and development of the self" (Merrill, 2015, p. 1859). Moreover, leaving the university can mark an essential biographical transition in adult life. Spanard (1990) reported that students who re-enter college after having dropped out are highly aware of the benefits of a HE degree and the impact this degree can have on their careers and personal satisfaction. This raises questions about what is meant by a successful experience of HE (Merrill, 2015) and from what perspective it is normalized. This article considers the student perspective, as until now, most of the drop-out studies were done from the institutional (university or college) view. The student perspective, on the other hand, involves an interest in subjectivity that is operationalized in this article by the concept of identity.

A few other authors have problematized this issue, for example when stating that "the assumption that HE automatically produces social justice is challenged by the growing phenomenon of 'voluntary' withdrawal amongst young working-class students" (Quinn, 2004, p. 58). This author uses the term voluntary drop-out for students who choose to leave before completion; moreover, she operationalizes dropping out as a class cultural narrative. Nevertheless, there is still limited (if any) empirical evidence about students who return to HE studies after dropping out. Not much is known about adult learner identities in general and almost nothing about $\mathrm{HE}$ students who return to $\mathrm{HE}$ with a drop-out experience or about what they have learned from it. The present article aspires to fill a part of this gap by focusing on the identity struggles of adult students who left university in the past and later return to study. These students who dropped out and now drop in are operationalized in the literature as adult returners (Slowey \& Schuetze, 2012). This group was chosen for two specific reasons: because of the possibility to more closely examine the experience of dropping out (and the ways of overcoming it) and for the opportunity to explore the difficulties with the widening participation of adults in HE and their identity struggles. The scope of the present study can be thus further specified in the following research question: What kind of narrative identity struggles are experienced by adult returners? 


\section{Methodology}

\section{Biographical design}

In biographical research (Merrill \& West, 2009), there is a time for reflection and self-negotiation, so that identity struggles can be discovered and understood (Thunborg et al., 2012); it is thus appropriate for the aim of this article. The narrative interview format was used as it "envisages a setting that encourages and stimulates an interviewee (who in narrative interview is called an 'informant') to tell a story about some significant event in their life" (Jovchelovitch \& Bauer, 2000, p. 2). In this case, the research project interviews solicited stories about the educational trajectories of returners, and thus potential university drop-outs could be identified during the interview.

In this study, narrative data were collected through audiotaped interviews lasting from 1 to 2 hours and were first inductively thematized and categorized in open coding and then analyzed through a second coding based on theoretical themes, including the concepts of agency and structure. Thematic codes were used, as the theory of biographical work by Bron and Thunborg (2017) builds on Mead's (1934) concept of the forming of the Self, Giddens' (1984) theory of the structuration, and the relation between structure ${ }^{3}$ and agency $^{4}$ (Bron et al., 2013 in Bron \& Thunborg, 2017; Thunborg \& Edström, 2010), and these concepts can be beneficial for understanding the processes of interaction between identities.

\section{Data provenance and ethical aspects of the study}

This article draws upon data from the qualitative part of a research project funded by the Czech Science Foundation (GA ČR) concerning non-traditional students studying for educational degrees in the Czech Republic. Students in this project's qualitative sample were at least 26 years old and had experienced a break in their educational trajectory - this was our criteria for being "nontraditional" (Novotný et al., 2019; Rozvadská \& Novotný, 2019) - and they were studying for educational degrees. In another study published in this issue (Brücknerová et al., in press), we described the narrative interviews and their contents in more detail.

\footnotetext{
3 Structure refers to "the underlying principles that shape the normative patterns within social groups" (Sewell, 1992 in Shanahan, 2009, p. 45)

$4 \quad$ Agency means an individual's ability to shape the world around them (Shanahan, 2009)
} 
The research project was approved by the Ethics Commission of Masaryk University. The ethical quality criteria applied in the data collection were the informed consent of the informants signed before each interview, anonymization of the data, and safe data storage. Qualitative methodologists also point out that "the ethical issue is not simply attaining the respondent's consent to have his or her story recorded and analyzed" (Frank, 2002, p. 115), as some issues are specific for narrative analysis. For example, the quotes from narratives were treated very carefully, as the stories they presented could lead to recognition of the storyteller even after anonymization.

\section{Description of the study sample}

For the purpose of this study, a sum of thirty biographical narratives of nontraditional students studying for educational degrees was re-examined employing secondary analysis with a new research question; from among them, those participants were identified who had a previous university drop-out experience. The final selection included eight respondents who returned to university after previously unsuccessful studies; their characteristics are shown in Table 1. After the examination of the study sample, it was discovered that the educational trajectory of these students follows various patterns of enrollment: (1) re-returners: they studied once successfully, then return to another field of study, drop out, and then re-return; (2) real returners: they dropped out (some of them multiple times) and now return; and (3) successful returners: they dropped out, returned later to attain a university degree, and now are back again to study for another degree. These three patterns are more of a continuum than categories, as there are some intersections between them, such as students who return repeatedly and have no previous successful HE experience. This is in line with the current evolution of adult education theory, which suggests that "the study of adult students should reflect a continuum, as opposed to a dichotomy of categories or characteristics" (Irvine, 2005, p. 256).

Table 1

Description of the study sample

\begin{tabular}{|c|c|l|l|l|}
\hline & Age & Gender & Educational trajectory & Career trajectory \\
\hline A & 42 & female & Real returner & Secretary \\
\hline D & 37 & female & Real returner & Secretary \\
\hline F & 57 & male & Real returner & Juvenile detention officer \\
\hline I & 35 & female & Successful returner & Teacher \\
\hline J & 39 & female & Real returner & Shop assistant, unemployed \\
\hline L & 50 & female & Real returner (multiple times) & Teacher \\
\hline X & 45 & female & Re-returner & Social worker \\
\hline$\check{Z}$ & 45 & female & Successful returner & Financial manager, unemployed \\
\hline
\end{tabular}




\section{Narrative data analysis}

After the examination of the study sample and the initial coding processes to explore the data, it was observed that the interactions among the identities of adult returners in $\mathrm{HE}$ and the eventual identity struggles that can occur are more visible in the stories as a whole (employing narrative analysis) than in open or thematic coding and coding sequences. This indicated that more complex issues are hidden behind these identity struggles. Thus the focus of the analytical part of this secondary analysis study was on the narrative analysis of these data.

Fist, the data were organized in accordance with Polkinghorne (1995), who stated that the goal of the organizational phase is to refine the research question and separate irrelevant or redundant information from that which will be analyzed, sometimes referred to as narrative smoothing. More concretely, the most important step in the analysis of the narratives was the schematic representation made for every life story. Each story was represented as a picture reflecting the informant's educational trajectory. This step was important for recognizing the diverse identities hidden in the narratives. It also enabled an analysis of the role of agency and structure in the stories. This representation was then used as a foundation for the more general schematization of identity processes found in the narratives, in order to find invisible patterns of the stories that can be seen in Figure 1.

Figure 1

Integration and disintegration of identities

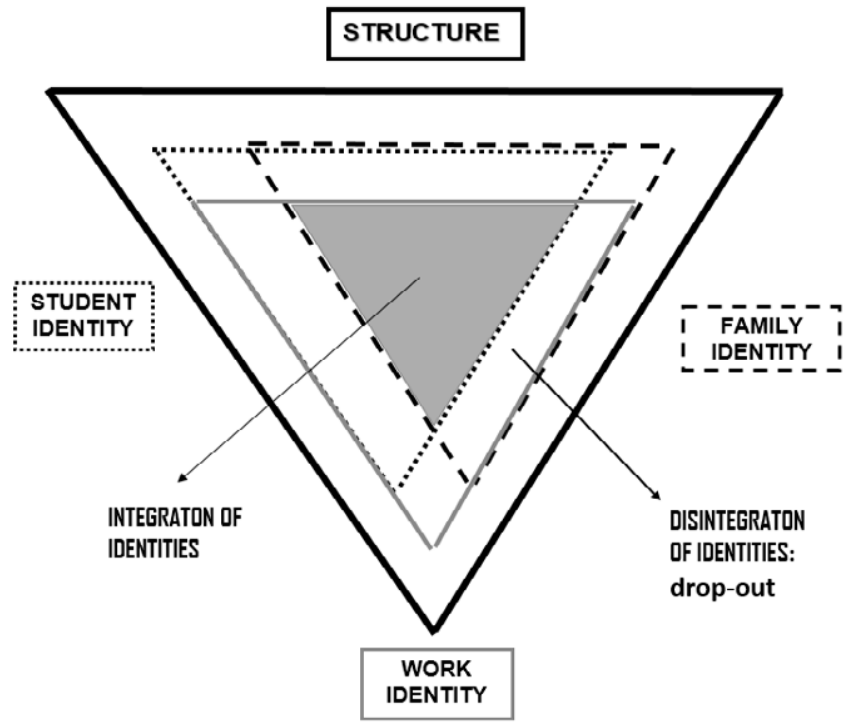

Note: Dropping out is seen as agency. 


\section{Results}

\section{Narrative identities of the adult returner}

The results presented in this article are the outcomes of a narrative analysis of the whole educational trajectory of informants from a diachronic view. These results are different from those from a synchronic view of the presence of adults in $\mathrm{HE}$, which emphasizes the roles of adults and the momentaneous interference of these roles, for example when a student has to prepare for an exam and cannot because of work or family responsibilities. The narrative analysis of the adult returners' stories identified three central identities of these students. These identities are the student identity, the work identity, and the familial identity. The revelation of the identities represented in the narratives of the informants was crucial for the further analysis and comprehension of the identity processes the informants encountered in their life stories.

The student identity is the first identity we think of when we consider the scope of the present study. The student identity of the returners may be experienced differently than those of traditional HE students. A statement by informant $\mathrm{X}$ illustrates the non-traditional student identity of these returner students: "I am an older, non-traditional student, because this is not the first school I am studying at and I do not need it for anything yet; I do not know if I will continue to work in this field at all." Noticeably, for this adult student, the student identity is expressed strongly in relation to future employability in the field she is studying and so with her work identity.

The second identity identified in the narratives of these students is the work identity. For informant L, working with children is the starting point for considering all other identities. After her first drop out (she has many in her story), she started to work as a language teacher at a high school in her hometown:

I jumped into the high school to teach [the language], and in the end, after various ups and downs, I've been there for twenty years, and aah there was a time when the headmaster didn't really want me to finish college because they were in need in a way, so I'm... I don't know how long I haven't solved it, for about three or four years. Still, then I found out that I enjoy the job because I come from a family, my grandmother and my greatgrandfather taught, and so it always drew me to children, I love children, and [the language], it's just a tool for me to get to the kids.

Further in her story, this informant talks about herself as paidotrope, as opposed to a logotrope. This means that she did not begin to work as teacher or to study the language in question because of her passion for the language (logotrope), but because of her passion for working with children (paidotrope). This distinction explains the nature of her work identity and what attributes she gives it. 
The third identity, the familial identity, is either connected with children, with a partnership, or with the family as a whole (family of origin or nuclear family). This identity can easily be the most important among the three for adult students, as this quote from informant $\mathrm{J}$ illustrates:

Because I just like to deal with things more in my personal life, which is more important to me now. My son is four and a half, so he's already quite big. He will go to kindergarten, then to school. Now he's with his dad; we keep changing him. Yeah, there is a new partner, so we just deal with a lot of other things. So the university is like really... When I say it... it doesn't matter so much.

In this quote, to explain why the student identity is not central for her ("university doesn't matter so much"), informant J speaks in detail about her familial identity. She identifies most with her identity as a mother (she provides details about it what it consists of) and a partner (she mentions both her former and her current partners).

Despite these specific examples for each identity, it has to be said that it is quite rare to find parts in the adult students' narratives that illustrate only one separate identity - it is more common to find them inter-related in the story, as in the example of the work and student identity of informant L. Based on the narrative approach to identity, this form of appearance in the narratives is a reflection of how it is in reality - these identities are interconnected with each other and they interact. For example, for informant L, her student identity is judged in the function of her work identity as a teacher and also in the function of her familial identity. She compares her vocation with the vocation of her grandparents, and later in her narrative she compared her studies with those of her daughter, who is also studying to become a teacher. According to informant L, her daughter is far more successful in validating her student identity, even in the outer world: "My daughter is already grown, she is studying at university, (...) she is studying very successfully (...)she is very passionate, and I look at her and say to myself, that's exactly what I wanted to do, but I'm happy that at least it's happening for my daughter, that she's happy." Informant L's student identity interferes here strongly with her familial identity; she identifies with her daughter and achieves fulfillment through her. This is in line with the theoretical conception of identity presented in the first chapter of this article, where identity is not only who I am, but also who I want to become.

Sometimes these identities can be disrupted. Each identity is contextualized within a structure: the principles that shape the normative patterns within a social group (Sewell, 1992 in Shanahan, 2009). For student identity, the structure is the university where the student is enrolled or the educational system as a whole. For work identity, it is the labor market or the current job of the person. For familial identity, it is the family, the partner and/or the 
child(ren). Alteration in one or more of the structures can lead to identity struggles. By way of illustration, we examine the example of informant $\mathrm{X}$ who experienced a change in the work structure that was accompanied by an identity struggle:

There was a change of leadership, and the new director brought his own management. They offered me the opportunity to stay there under the same salary conditions, but basically, it would be far less responsibility and less exciting work. So I refused, and I left. Well, and at the same time, that job didn't fulfil me that much anymore.

The change in the job of informant $\mathrm{X}$ led to a change in her work identity. After this, she decided to enroll for an educational degree, so it brought a change in the form of yet another identity, the student identity. By looking deeper within the identity struggles, alterations in the structure or in the agency can be found. As agency and structure are linked to the identities, these alterations also lead to changes in one of the identities and therefore, even in changes in the relationships between the identities.

\section{Integration and disintegration of identities}

These changes in the relationships between identities can be resolved by reintegrating them to a new identity symbiosis or by the opposite - the disintegration of the symbiosis of these identities. The integration occurs when all the identities are successfully integrated into the identity portfolio and thus in the biography of the student. By contrast, the disintegration can happen as a result of identity struggles, if they are so incongruous that they cannot be integrated and there has to be an important change in one of them; if the one that must change is student identity, this can result in a drop out.

Informant D's story can serve as an example of a successful identity integration. Her familial identity is represented by the ideal study and work model she had in her sister who gave informant $\mathrm{D}$ the needed impulse to begin to work in the educational sector, the starting point for further educational decisions by the informant. The struggle at her work, where she did not understand the problems of students she was supposed to help, was successfully integrated into her biography and led her to enrolling in university studies. "I didn't understand their issues, the students who came to me and turned to me for some help. And along the way, I started studying, and I understood it all - how it works for them, and what, so I can help even though I'm still a secretary." In her story, although her first attempt to study was not successful (she did not pass an exam), she returned immediately after dropping out and continued as if that had never happened, and this was possible by virtue of the successful integration of her two identities - the work identity and the student identity. 
On the other hand, the disintegration of identities can lead to the abandonment of one of the identities of adult learners. If it results in leaving the student identity, this can lead to dropping out of tertiary studies. Sometimes these disintegrations can even succeed one after another, which is the story of informant $\mathrm{L}$.

And so I went through several universities, I went through a total of four or five universities, and I have experienced various systems, how, where, who teaches, I was at two faculties of education, actually three times at faculties of philosophy, and thus today I have the chance to know why it all happened this way, that if I had gone to the Faculty of Education, because I am more of a paidotrope than a logotrope, so that would be much easier.

In this quote, informant L identifies the struggle between her work identity (paidotrope) and her student identity (her studies at faculties of philosophy, where the language studies are rather logotrope orientated) as the reason of her drop-outs. The analysis of her story identified that the struggles were often not only between these two central identities, but even among all three. It was due to the fact that her familial identity also strongly interfered, especially when her daughter was small. The struggle among all three identities could be a reason for her repeated drop-outs.

The story of informant $\mathrm{X}$ illustrates both the disintegration and integration of identities within one life story: first it led to dropping out and later it did not (for the same two identities). Within the narrative of this informant, two distinct cases of the transformation of the relationship between familial identity and student identity were identified. At first, the identities disintegrated - in a drop out. "I went to study at the same university and the same field I'm studying now. It was the field of teaching vocational subjects. I didn't finish this field just before the state examinations; it was, it was for... I don't even know why. Only for family reasons, my father died." But later, these very identities, the familial and the student identities, were reintegrated when this informant returned to university to support her husband who did not yet have a higher education degree: "Why I decided to do this last school again was that I have a husband without a university degree who suffered a little from it, and my daughter and I decided that we would just support him and that the three of us would try the same school. Just graduate." When analyzing the whole life story of this informant, it became evident that first she studied successfully in economics, then she dropped out from an educational degree, and now she has returned for another attempt to earn the same educational degree.

For informant A, who left her first studies because she did not feel that it was the right field for her, there was a conflict with her original familial identity and her student identity. Paradoxically, later, her new familial identity 
was the vital impulse to start to study again: "The new family when I married my husband was very academic. And when, my husband always told me like, Isn't it a shame? Don't you just want to try it? So somehow my husband actually motivated me to re-enroll in university." Similarly, informant J dropped out from her first studies, just because she told herself that it was not fair to study a program and at the same time not work in the field related to it. The interaction between her student identity and her work identity that did not fit together. In other words, the work identity did not match with the university structure that shaped her first student identity:

Because after those three years, I said to myself that I didn't want to do it, and that it would just be stupid to have a degree, meaning that it would be terribly unfair that I study something and I just don't want to do it then. And that it would be uncomfortable to say, "Oooh, I'm studying special education, but I'm not doing it at all."

In this case, this disintegration of identities led to this informant abandoning her student identity, an identity to which she never did truly adhere. It has to be noted that her path to the successful adoption of her student identity was also complicated during her second enrollment at university (the current one), illustrated by this fragment of her story:

And I remember I was at one of the last lectures, and there was a man who worked, I don't know, in a crisis center or something like that. He played a video about how children learn from their parents. And it starts quite innocently, it's kind of cute, and then it goes on, that the mother is on the escalators, I think she's throwing a cigarette butt somewhere, the child is standing behind her and then he's throwing out the trash. Well, it ended with the parents just kind of screaming at their baby, and that dad did this to the mom. Well, I wasn't there anymore, yeah, I just stayed at the screaming and then I ran away because I knew she was going to be slapped by the dad. Which was just such an annoying current topic for me, so I ran away. I ran away from that lecture; I bumped into the door, I wanted to open it, and it didn't work. So everyone looked at what was happening. And Daisy just came down the hall behind me, and we breathed it out together. And then she says, "Um, that's interesting, isn't it?" I say, "Well, that's interesting." "And it's probably not a coincidence, is it?" I say, "Um, maybe not." Somehow I decided it was probably not worth it, that I would run away from him [her partner] with John [her son].

Within this episode, there are two conflicting identities - the student identity and the familial identity. The familial identity is represented by the abusive behavior of the informant's partner. Finally, this informant decided to reconcile this identity struggle, which was susceptible to leading to another identity disintegration (to a new drop-out) by breaking with her partner, by breaking down this part of her familial identity. She managed to solve it by leaving - this time not by leaving the student identity as she did before, but by leaving one part of her dysfunctional familial identity, the abusive partner. 
Finally, there are also life stories where the drop-out experience was successfully integrated into the biography, as there was already a success that precedes the current university enrollment.

I met my first husband during the revolution, and I soon got pregnant (laughs). I got married, and I didn't finish the first school. And instead, I started, I started working. I started, uh, learning fast the basics of accounting, how to do business... And then there were the wild 90s; private business started to be possible... I was very interested, it was exciting, and it resulted in starting studying law. And I graduated in it in 2000.

This quote can be interpreted as an identity struggle between the student identity and familial identity, which finally led to their disintegration dropping out. However, the informant presents it as a natural consequence of events, so the role of the drop-out does not seem to be crucial in her educational and biographical experience.

\section{Discussion}

This study makes two main contributions to the literature on identity formation in HE. First, it presents new findings about previously unsuccessful HE students who are now non-traditional adult returners. For many adult students, the transition into HE from the world of work and family responsibilities is an intense experience as it challenges their sense of themselves (Brunton \& Buckley, 2020). This study showed that these students are dealing with three main identities and their interaction: student identity, work identity, and familial identity.

The present article can also be seen as a contribution to the debate on struggles for adultification (Bourgeois et al., 1999) in current HE. Bourgeois et al. (1999, p. 132) explain that the presence of adult students "challenges the social construction of what the university's mission and priorities should be." Within this context, it is probable that dropping out from university studies is susceptible to generating or being generated by identity struggles in the life stories of adult students. Reay (2003) pointed out that the "recent emphasis on widening participation and access to higher education assumes a uniformly positive process, yet the reality (...) is often confusing and fraught with difficulties" (p. 301). Our analysis provides new findings about the nature of these identity struggles encountered by adult learners after enrolling in HE with previous life and drop-out study experiences. The final result of the interactions among the identities of these adult students can be integrated into some kind of identity symbiosis - identity integration, or it can lead to the opposite - identity disintegration. 
Thunborg et al. (2012) investigated the forming of learning identities amongst non-traditional students in Swedish HE through the concept of biographical work, according to which identity transformation always starts with identity struggles. In the present study, the disintegration of identities can be seen as process of identity transformation and the narratives of returners really show that disintegration is a result of identity struggles. But in the second possibility, that of integration, there need not be a struggle. When there is a struggle, in order to lead to integration, it has to be incorporated into the biography and resolved without a disconnection from one of the identities.

According to the authors of the typology of adult learners that coined the term "returners" (Slowey \& Schuetze, 2012, p. 24), returners "often see their higher education experience as woven into the fabric of their lives, rather than being discrete and finite." In this study, returners are dealing with constant alternations in the phases of integration and disintegration in their identity portfolio (Brunton \& Buckley, 2020). But the results of this article additionally show that for some adult returners, the drop out was successfully integrated into their biography; for others, it was not and the disintegration of identities (and the dropping out) repeat even multiple times. It is not yet clear why only some returners manage to integrate themselves successfully. One possible explanation is that it is extremely difficult to manage the challenge when more than two identities are in conflict.

\section{Conclusion}

This presentation of identity struggles was born within an analysis of adult returners' narratives. The starting point was the narrative representation of the students' previous drop-out experience. It provided rich data on identity processes of adult learners; the patterns of integrating and disintegrating phases of identity struggles were quite visible. However, it is highly probable that these patterns are universal and true for identity struggles other than those of drop-outs. Further analysis of adult learner narratives should be carried out to test this presumption.

\section{Acknowledgements}

The text is published with the support of the Czech Educational Research Association and the Council of Scientific Societies of the Czech Republic at the Czech Academy of Sciences. It was presented at the XXVIII. Czech Educational Research Association Conference 2020. The study is an outcome 
of the "Non-Traditional Students Studying for Education Degrees in Tertiary Education within the Czech Republic" research project funded by the Czech Science Foundation (18-15451S). The author would like to thank all the members of the core research project team for their contributions to the collection of the research data and their feedback on this article as well as the anonymous reviewer whose valuable remarks considerably improved the final version of this article.

\section{References}

Beck, U. (1992). How modern is modern society? Theory, Culture \& Society, 9(2), 163-169. https://doi.org/10.1177/026327692009002011

Beck, U., Giddens, A., \& Lash, S. (1994). Reflexive modernization: Politics, tradition and aesthetics in the modern social order. Stanford University Press.

Bonham, L. A., \& Luckie, J. A. I. (1993). Taking a break in schooling: Why community college students stop out. Community College Journal of Research and Practice, 17(3), 257-270. https:// doi.org/10.1080/0361697930170306

Bourgeois, É., Duke, C., Guyot, J.-L., \& Merrill, B. (1999). The adult university: The Society for Research into Higher Education. Open University Press.

Brickhouse, N. W., \& Potter, J. T. (2001). Young women's scientific identity formation in an urban context. Journal of Research in Science Teaching, 38(8), 965-980. https://doi.org/10.1002/ tea.1041

Bron, A., \& Thunborg, C. (2017). Theorising biographical work from non-traditional students' stories in higher education. International Journal of Contemporary Sociology, 54(2), 112-127.

Bruner, J. (1996). The culture of education. Harvard University Press.

Brücknerová, K., Rozvadská, K., Knotová, D., Juhaňák, L., Rabušicová, M., \& Novotný, P. (2020). Educational trajectories of non-traditional students: Stories behind numbers. Studia Paedagogica, 26(4), 93-114. https://doi.org/10.5817/SP2020-4-5

Brunton, J., \& Buckley, F. (2020). 'You're thrown in the deep end': Adult learner identity formation in higher education. Studies in Higher Education. Advance online publication. https://doi.org/10.1080/03075079.2020.1767049

Chappell, C., Rhodes, C., Solomon, N., Tennant, M., \& Yates, L. (2003). Reconstructing the lifelong learner: Pedagogy and identity in individual, organisational and social change. Routledge.

Ecclestone, K. (2007). An identity crisis? Using concepts of 'identity', 'agency' and 'structure' in the education of adults. Studies in the Education of Adults, 39(2), 121-131. https://doi.org /10.1080/02660830.2007.11661544.

Frank, A. W. (2002). Why study people's stories? The dialogical ethics of narrative analysis. International Journal of Qualitative Methods, 1(1), 109-117. https://doi.org/10.1177/ 160940690200100102

Gee, J. P. (1999). An introduction to discourse analysis: Theory and method. Routledge.

Giddens, A. (1984). The constitution of society: Outline of the theory of structuration. University of California Press.

Giddens, A. (1991). Modernity and self-identity: Self and society in the late modern age. Stanford University Press. 
Grau-Valldosera, J., Minguillón, J., \& Blasco-Moreno, A. (2019). Returning after taking a break in online distance higher education: From intention to effective re-enrollment. Interactive Learning Environments, 27(3), 307-323. https://doi.org/10.1080/10494820.2018.1470986

Irvine, H. (2005). Adults returning to education: Gender and identity processes. In P. Weinreich \& W. Saunderson (Eds.), Analysing identity: Cross-cultural, societal and clinical contexts (pp. 255-276). Routledge.

Jovchelovitch, S., \& Bauer, M. W. (2000) Narrative interviewing. In M. W. Bauer \& G. Gaskell (Eds.), Qualitative researching with text, image and sound: A practical handbook (pp. 57-74). Sage.

Lave, J., \& Wenger, E. (1991). Situated learning: Legitimate peripheral participation. Cambridge University.

MacFarlane, K. (2018). Higher education learner identity for successful student transitions. Higher Education Research \& Development, 37(6), 1201-1215. https://doi.org/10.1080/072943 60.2018.1477742

Mazouch, P., Ptáčková, V., Fischer, J. \& Hulík, V. (2018). Students who have unsuccessfully studied in the past - Analysis of causes. Journal on Efficiency and Responsibility in Education and Science, 11(3), 65-71. https://doi.org/10.7160/eriesj.2018.110303

McAdams, D. P. (1985). Power, intimacy, and the life story: Personological inquiries into identity. Guilford Press.

McAdams, D. P. (1993). The stories we live by: Personal myths and the making of the self. Guilford Press.

McAdams, D. P. (1996). Personality, modernity, and the storied self: A contemporary framework for studying persons. Psychological inquiry, 7(4), 295-321. https://doi.org/10.1207/ s15327965pli0704_1

McAdams, D. P. (2001). The psychology of life stories. Review of General Psychology, 5(2), 100-122. https://doi.org/10.1037/1089-2680.5.2.100

McAdams, D. P., \& McLean, K. C. (2013). Narrative identity. Current Directions in Psychological Science, 22(3), 233-238. https://doi.org/10.1177/0963721413475622

Mead, G. H. (1934). Mind, self and society: A standpoint from a social behaviorist. University of Chicago Press.

Mercer, J. (2010). Exploring the processes of self-development encountered by adult returners to higher education: A lifespan psychology perspective. Psychology Teaching Review, 16(1), $24-36$.

Merrill, B. (2015). Determined to stay or determined to leave? A tale of learner identities, biographies and adult students in higher education. Studies in bigher education, 40(10), 1859-1871. https://doi.org/10.1080/03075079.2014.914918

Merrill, B., \& West, L. (2009). Using biographical methods in social research. Sage.

Novotný, P., Brücknerová, K., Juhaňák, L., \& Rozvadská, K. (2019). Driven to be a nontraditional student: Measurement of the academic motivation scale with adult learners after their transition to university. Studia Paedagogica, 24(2), 109-135. http://dx.doi.org/10.5817/ SP2019-2-5

Polkinghorne, D. E. (1995). Narrative configuration in qualitative analysis. International Journal Of Qualitative Studies in Education, 8(1), 5-23. https://doi.org/10.1080/0951839950080103

Quinn, J. (2004). Understanding working-class 'drop-out' from higher education through a sociocultural lens: Cultural narratives and local contexts. International Studies in Sociology of Education, 14(1), 57-74, https://doi.org/10.1080/09620210400200119 
Quinn, J., Thomas, L., Slack, K., Casey, L., Thexton, L. W., \& Noble, J. (2005). Retbinking working-class 'drop-out' from higher education. Joseph Rowntree Foundation. https://www.jrf. org.uk/report/rethinking-working-class-drop-out-university

Reay, D. (2003). A risky business? Mature working-class women students and access to higher education. Gender and Education, 15(3), 301-317. http://dx.doi.org/10.1080/09540250303860

Ricoeur, P. (1992). Oneself as another. University of Chicago Press.

Roth, W.-M., Hwang, S., Goulart, M. I. M., \& Lee, Y. J. (2005). Participation, learning and identity: dialectical perspectives. Lehmanns Media.

Rozvadská, K., \& Novotný, P. (2019). The Structure of non-traditional students' motives for entering higher education. Form@re-Open Journal Per La Formazione in Rete, 19(2), 133-148. https://doi.org/10.13128/formare-25262

Shanahan, M.-C. (2009). Identity in science learning: Exploring the attention given to agency and structure in studies of identity. Studies in Science Education, 45(1), 43-64. https://doi. org/10.1080/03057260802681847

Schnepf, S. (2015). University drop-outs and labor market success. IZA World of Labor, 2015(182). https://doi.org/10.15185/izawol.182

Sfard, A., \& Prusak, A. (2005). Telling identities: In search of an analytic tool for investigating learning as a culturally shaped activity. Educational Researcher, 34(4), 14-22. https://doi. org/10.3102/0013189X034004014

Slowey, M., \& Schuetze, H. G. (2012). All change - no change? Lifelong learners and higher education revisited. In H. G. Schuetze \& M. Slowey (Eds.), Globalperspectives on higher education and lifelong learners (pp. 1-34). Routledge.

Spanard, J. M. A. (1990). Beyond intent: Reentering college to complete the degree. Review of Educational Research, 60(3), 309-344. https://doi.org/10.3102/00346543060003309

Thunborg, C., \& Bron, A. (2019). Being in constant transition or recurrent formation: Non-traditional graduates' life transitions before, during and after higher education in Sweden. Studies in the Education of Adults, 51(1), 36-54. https://doi.org/10.1080/02660830. 2018.1523102

Thunborg, C., Bron, A., \& Edström, E. (2012). Forming learning identities in higher education in Sweden. Studies for the Learning Society, 2(2-3), 23-34. https://doi.org/10.2478/v10240012-0002-5

Thunborg, C. \& Edström, E. (2010). Changing learning identities and higher education. In B. Merrill \& J.G. Monteagudo (Eds.), Educational journeys and changing lives: Adult student experiences (pp.76-87). Digital@Tres.

Woosley, S. (2003). Stop-out or drop-out? An examination of college withdrawals and re-enrollments. Journal of College Student Retention: Research, Theory \& Practice, 5(3), 293-303. https://doi.org/10.2190/6NW2-FUJ4-4ATU-EKHC

\section{Corresponding author}

Katarína Rozvadská

Department of Educational Sciences, Faculty of Arts, Masaryk University, Brno, Czech Republic E-mail: rozvadska@phil.muni.cz 